\title{
Pharmaciana
}

Vol.11, No.1, March 2021, Page. 153-162

ISSN: 2088 4559; e-ISSN: 24770256

DOI: $10.12928 /$ pharmaciana.v11i1.18888

\section{The protective effect of Phyllanthus emblica Linn. extract against doxorubicin-induced hepatotoxicity in rats}

\author{
Eka Susilawati, I Nyoman Ehrich Lister*, Edy Fachrial \\ Department of Biomedical Sciences, Faculty of Medicine, Universitas Prima Indonesia, \\ Jl. Belangga No. 1, Sei Putih Tengah, Kec. Medan Petisah, Kota Medan, Sumatera Utara, Indonesia
}

Submitted: 01-12-2020

Reviewed: 01-02-2021

Accepted: 30-03-2021

\begin{abstract}
Recently many researches have been carried out on Malacca fruit extract and its potential protective effect on in vivo organ toxicity. However, there is still no research on the protective effect of Malacca (Phyllanthus emblica L.) fruit extract on induced hepatotoxicity of anticancer drugs, especially doxorubicin in rats. The objective of this study is to determine the potential protective effect of ethanol extract of Malacca fruit ( $P$. emblica L.) against doxorubicin-induced hepatotoxicity in rats. A preliminary phytochemical test was done followed by administration extract into doxorubicin-induced rats. Histological studies were carried out to observe the effect of the extract on liver tissue. Phytochemical test results show that the ethanol extract of Malacca fruit contains flavonoids, phenols, tannins, triterpenoids, terpenoids, and alkaloids. The increasing value of ALT and ALP of doxorubicin-induced liver tissue proved the toxicity in liver tissue caused by doxorubicin. The ethanol extract of $P$. emblica $L$. at dosage $200 \mathrm{mg} / \mathrm{kg} \mathrm{BW}$ and dosage $400 \mathrm{mg} / \mathrm{kg}$ BW on doxorubicin-induced rats were successfully played as an antioxidant to decrease the ALT and ALP values and improve liver tissue doxorubicin-induced by normal hepatocytes more dominant than lysis and less mark of bleeding and congestion of blood vessels.
\end{abstract}

Keywords: Phyllanthus emblica L., malacca fruit, doxorubicin hepatoxicity, hepatoprotective

\section{*Corresponding author:}

I Nyoman Ehrich Lister

Department of Biomedical Sciences, Faculty of Medicine ,Universitas Prima Indonesia

Jl. Belangga No. 1, Sei Putih Tengah, Kec. Medan Petisah, Kota Medan, Sumatera Utara, Indonesia

Email:nyoman@unprimdn.ac.id 


\section{INTRODUCTION}

Based on WHO data in 2008, there are as many as 36 million people in the world who suffer from Non-Communicable Diseases (NCD) of the 57 million people who died. The proportion of causes of death of NCD in people aged less than 70 years is cardiovascular disease (39\%), cancer (27\%), lung disease - chronic respiratory and gastrointestinal diseases each cause $30 \%$ of deaths, and the rest is caused by diabetes mellitus (WHO, 2010). According to the WHO, deaths caused by NCD are expected to increase continuously throughout the world, with the proportion most often found in groups of developing countries. In 2030, there will be a real epidemiological transition globally, at regional and national levels with a shift in the number of cases of infectious diseases to degenerative diseases and NCDs, including cancer, diabetes, and heart disease. The increase in the incidence of degenerative diseases is thought to be related to lifestyle risk factors, population growth, and increased life expectancy (Kementerian Kesehatan Republik Indonesia, 2013).

In cancer patients, organ dysfunction is a frequent phenomenon, especially impaired liver function is the most common case and is one of the factors considered in cancer patients' treatment. Doxorubicin (adriamycin), an anthracycline class, is an anticancer drug widely used to treat broadspectrum cancer patients. Several studies have found hepatotoxicity found in cancer patients, mostly due to the toxicity of the anticancer drugs used, including the use of doxorubicin and a small part due to a history of previous hepatic abnormalities (Damodar et al., 2014). Damodar et al. (2014) reported that there was a strong correlation to the occurrence of hepatotoxicity in breast cancer patients who received doxorubicin injection, where $30.4 \%$ of breast cancer patients experienced hepatotoxicity marked by an increase in serum glutamic oxaloacetic transaminase (SGOT), serum glutamic pyruvic transaminase (SGPT), direct bilirubin levels, and total bilirubin levels (Damodar et al., 2014). King and Perry (2001) suggested that the use of doxorubicin will affect cell membrane function through DNA intercalation and free radical formation in hepatocytes (Injac and Strukelj, 2008; King and Perry, 2001). Furthermore, Pedrycz et al. (2004) found that doxorubicin can cause apoptosis of hepatocyte cells in adult rats. Although the underlying mechanism is unclear, it is thought to be related to the production of free radicals and oxidative tension that triggers cell injury, including hepatocytes and other body cells (Sliai, 2015). The hepatotoxicity caused by doxorubicin and the belief in its toxicity mechanism through the free radicals production resulted in several new approaches oriented to the natural antioxidants using. Many natural antioxidants have been studied for their content and benefits, such as vitamins (E, A, C, and carotenoids), coenzyme Q, flavonoids, polyphenols, selenium, and olive oil (Injac and Strukelj, 2008).

Many plants and their extracts have a hepatoprotective effect by increasing their antioxidant status so that plant-derived drugs play an essential role in managing a liver disease or disorders (Seif, 2016). The Indian gooseberry or Malacca (Phyllanthus emblica L.) contains high content of tannins, flavonoids, phenolic compounds, saponins, terpenoids, ascorbic acid, carbohydrates, and other compounds (Hasan et al., 2016). The content of total phenol compounds (TPC), mostly of gallic acid, comes from the Malacca fruit and seed. TPC is a potent antioxidant source and plays a vital role in scavenging free radical groups in maintaining a balance of redox potential in degenerative disorders (Hasan et al., 2016). The water extract of Malacca fruit in another study was found as a strong potential in scavenging free radicals and inhibiting the ROS (Reactive Oxygen Species) production (Hasan et al., 2016). Other than phenolic compounds, flavonoids as secondary metabolites of Malacca fruit extract have also been studied by Sharma et al. (2010). In addition, it was found that Malacca extract's flavonoid compounds can be used as chemotherapy agents and nutrition since it has excellent antioxidant potential and can be well absorbed through the gastrointestinal tract (Hasan et al., 2016). Studies about the hepatoprotective potential of Malacca fruit extract have been reported. Previously, Tasduq et al. (2005) reported that hydroalcoholic extract of $P$. emblica fruit acted as hepatoprotective against anti-tuberculosis drug-induced hepatic 
injury in rats. The protective action was carried out through the antioxidant mechanism, membrane stabilizing, CYP 2E1 enzyme inhibition. Another study found that $P$. emblica L fruit extract with the dosage of $75 \mathrm{mg} / \mathrm{kg}$ per day can improve the recovery of rat liver cell by increasing the IL-1 $\beta$ levels, aspartate transaminase (AST) levels, and alanine aminotransferase (ALT) levels back to normal values (Charmkar and Singh, 2017). A histopathological study on the liver tissues of rats treated with Malacca fruit extract has also been carried out. This study used paracetamol as an inducer of hepatotoxicity and the result showed the ability of $P$. emblica $\mathrm{L}$ extract to reduce toxicity and liver damage (Hasan et al., 2016). Another study also found that the protective effect of hydroalcoholic extract of $P$. emblica $L$. fruit on chronic hepatoxicity induced by carbon tetrachloride $\left(\mathrm{CCl}_{4}\right)$ and thioacetamide in rats by accelerating the regenerative activity of the liver cells of the rats tested (Mir et al., 2007).

From previous studies, the hepatoprotective effect of Malacca fruit extract (P. emblica L.) on hepatotoxicity induced by anticancer drugs, especially doxorubicin in experimental rats, has not been discovered. Furthermore, it is necessary to compare the hepatoprotective effects through liver function tests (ALT and ALP levels) and histopathological tests of the rat's liver tissues. Thus, the purpose of this study observes the potential protective effect of the Malacca fruit (P. emblica L.) ethanolic extract against doxorubicin-induced hepatotoxicity in rats.

\section{MATERIALS AND METHOD Materials}

Malacca fruits (P. emblica L.) were obtained from around Medan and were used as the plant materials in this study. The fruits were authenticated by a botanist from Biology Department, Universitas Sumatera Utara. The chemical used were acetic anhydride, iron (III) chloride, magnesium powder, mercury (II) chloride, potassium iodide, iodine, 2,2-diphenyl-1 picrylhydrazyl (DPPH), bismuth (III) nitrate, hematoxylin solution, and eosin were purchased from SigmaAldrich, USA. Doxorubicin-HCl was purchased from Kalbe, Indonesia. Phosphate buffer, chloroform, hydrochloric acid, sulfuric acid, amyl alcohol, and ethanol were obtained from SmartLab, Indonesia.

\section{Experimental Animals}

Male Wistar rats (Rattus novergicus) weighed 150-250 g (2 months old) were selected for this study and conditioned for 1 week to adjust to their environment. These rats were divided into 5 groups which consisted of 5 rats in each group. This study has been passed as ethical by the Health Research Ethics Committee of Universitas Prima Indonesia with an approval number: 012/KEPK/UNPRI/VIII/2020.

\section{Methods \\ Sample extraction}

The preparation and extraction of samples were determined by the previous method including some modifications (Nur et al., 2017). P. emblica fruits were dried at $50^{\circ} \mathrm{C}$ for two days and ground into powder, resulted in $1000 \mathrm{~g}$ of sample powder. Fruit powder samples were extracted with $4000 \mathrm{ml}$ of $96 \%$ ethanol (v/v) and submitted to maceration for $24 \mathrm{~h}\left(25^{\circ} \mathrm{C}\right)$. Subsequently, the mixtures were filtered and the extraction process was repeated twice. Later, the extracts were concentrated at $50^{\circ} \mathrm{C}$ using a rotary evaporator and a $248 \mathrm{~g}$ yield of extract was obtained.

\section{Phytochemical screening}

The extract of $P$. emblica was evaluated by qualitative reactions of common plant secondary metabolites. The screening was carried out for flavonoids, alkaloids, tannins (Nurhasnawati et al., 2019), saponins (Akinpelu et al., 2014), phenols (Godghate and Sawant, 2013), steroid, terpenoids (Edeoga et al., 2005), triterpenoid (Alabri et al., 2014). The changing of color, frothing, or precipitate formation was used for the test response. 


\section{Evaluation of hepatic biochemical markers}

The evaluation of hepatic biochemical markers has followed the previous methods with modification (Rahmani et al., 2018). Twenty five male rats (R. novergicus) were weighed $200 \mathrm{~g}$ and randomly divided into 5 groups (5 rats in each group). The dosage of the $P$. emblica L. extract was given followed a previous study (Sultana et al., 2005). All foods and drinks were given the same to all treatment groups with no additional provision of fluids or other types of food in the doxorubicin group.

Group A : No treatment for 14 days

Group B : Doxorubicin was administrated intraperitonially $\left(25 \mathrm{mg} / \mathrm{kg} \mathrm{BW}\right.$ on $12^{\text {th }}, 13^{\text {th }}$, and $14^{\text {th }}$ day)

Group C : P. emblica L. extract was given orally $(200 \mathrm{mg} / \mathrm{kg} \mathrm{BW})$ for 14 days

Group D : P. emblica L. extract was given orally $(200 \mathrm{mg} / \mathrm{kg} \mathrm{BW})$ for 14 days, and doxorubicin for 3 days

Group E : P. emblica L. extract was given orally (400 mg/kg BW) for 14 days, and doxorubicin for 3 days

One day after the administration of the last dose, the mice were euthanized and the liver organ was immediately removed and washed with saline. Then $10 \%$ of the liver tissues were homogenized in buffered phosphate $(\mathrm{pH}=7.4)$ and centrifuged at $3000 \mathrm{rpm}$ for $20 \mathrm{~min}$ at $4^{\circ} \mathrm{C}$. The enzymatic activity alanine aminotransferase (ALT) and alkaline phosphatase (ALP) were measured based on the previous methods (Kanthe et al., 2017; Rahmani et al., 2018).

\section{Histological studies}

The liver histology study has done based on the previous methods by Rahmani et al., (2018) and Salouege et al., (2014). Small pieces of liver tissue were fixed in $10 \%$ formalin for histopathological studies and the tissue processing was done as a routine. Five-micron sections were obtained, stained with Harris Hematoxylin \& Eosin, and assessed for any changes in the histological structure under a light microscope. Analysis was carried out qualitatively by observing the condition of the hepatocytes and blood vessels.

\section{Statistical Analysis}

Values were expressed in terms of Mean \pm Standard error of mean (SEM). One-way ANOVA was done to determine the significance of inter-group differences. $p<0.05$ was considered statistically significant.

\section{RESULT AND DISCUSSION \\ Phytochemical screening}

Investigation of the natural sources as therapeutic agents cannot be separated from phytochemical screening techniques. This technique is used to analyze secondary metabolites found in plant extracts (Srivastava et al., 2014). In this study, screening tests were done qualitatively and the result is present in Table 1 . 
Table 1. The phytochemicals present in Phyllanthus emblica L. (Malacca) fruit extracts

\begin{tabular}{lcc}
\hline \multirow{2}{*}{ Compounds } & \multicolumn{2}{c}{ Result } \\
\cline { 2 - 3 } & $\boldsymbol{P .}$ emblica L. extract & Observation \\
\hline Alkaloids & $(+)$ & Orange \\
Flavonoids & $(+)$ & Yellow/Orange \\
Phenolics & $(+)$ & Green/Blue/Black \\
Steroids/Triterpenoids & $(+)$ & Orange \\
Terpenoids & $(+)$ & Purple \\
Tannins & $(+)$ & Red/Orange Layer \\
\hline
\end{tabular}

$+=$ Present, $-=$ Absent

Phyllanthus emblica L. (Malacca) fruit contains various bioactive chemicals. Table 1 shows the presence of alkaloids, flavonoids, phenolics, steroids/triterpenoids, terpenoids, and tannins. Previously, Sriwatcharakul (2020) and Luo et al. (2011) found that P. emblica L. seed extracts contained flavonoids, phenolic, tannin, saponins, and, alkaloids as secondary metabolites. Chaphalkar et al. (2017) also found that P. emblica L. (Malacca) bark-extract contained phenolic, flavonoids, and tannins. Previous findings suggested that the phytochemical of P. emblica L. (Malacca) have a potential effect as an anti-inflammatory (Wang et al., 2017), anti-microbial, antioxidant, anti-collagenase, and anti-elastase (Mayachiew and Devahastin, 2008).

\section{Biochemical results}

The hepatic biochemical markers measurement was conducted to evaluate ALT and ALP levels from rats with various treatments. In identifying the liver's toxicity, ALT was used as a marker for cytotoxic hepatic injury as it is mainly found in the liver. Along with ALT, ALP is also used since the elevation of this serum enzyme indicates cholestatic injury (Zimmermann-Ivol et al., 2004). The result of the activity of ALT and ALP present in Table 2.

Table 2. The alanine aminotransferase (ALT) and alkaline phosphatase (ALP) enzyme activity in different treatments on doxorubicin-induced rats

\begin{tabular}{lcc}
\hline \multirow{2}{*}{\multicolumn{1}{c}{ Treatments }} & \multicolumn{2}{c}{ Biochemical Parameter } \\
\cline { 2 - 3 } & ALT $(\mathbf{U} / \mathbf{I})$ & ALP(U/I) \\
\hline Normal & $95.60 \pm 2.42$ & $225.00 \pm 12.21$ \\
Doxorubicin, 25 mg/kg BW (Negative Control) & $170.40 \pm 8.58$ & $470.00 \pm 49.01$ \\
P. emblica $\mathrm{L}$ extract, $200 \mathrm{mg} / \mathrm{kg} \mathrm{BW}$ & $105.80 \pm 5.30$ & $265.60 \pm 26.89$ \\
P. emblica $\mathrm{L}$ extract, $200 \mathrm{mg} / \mathrm{kg} \mathrm{BW}+$ Doxorubicin & $126.60 \pm 8.25$ & $397.00 \pm 7.05$ \\
P. emblica $\mathrm{L}$ extract, $400 \mathrm{mg} / \mathrm{kg} \mathrm{BW}+$ Doxorubicin & $118.40 \pm 5.52$ & $320.40 \pm 18.92$ \\
\hline
\end{tabular}

Table 2 shows the doxorubicin treatments increased the level of ALT and ALP to $170.40 \pm$ 8.58 and $470.00 \pm 49.01$ compared with normal treatment with $95.60 \pm 2.42$ and $225.00 \pm 12.21$ U/I, respectively. The treatments only with P. emblica L. extract $200 \mathrm{mg} / \mathrm{kg} \mathrm{BW}$ decreased the serum activity for ALT $105.80 \pm 5.30$ and ALP $265.60 \pm 26.89$, similar to normal group treatment. The serum liver enzyme activities reduced in the group treatments of doxorubicin with $P$. emblica L. extract $200 \mathrm{mg} / \mathrm{kg} \mathrm{BW}$ (ALT: $126.60 \pm 8.25$ and ALP: $397.00 \pm 7.05 \mathrm{U} / \mathrm{I}$ ) and $400 \mathrm{mg} / \mathrm{kg} \mathrm{BW}$ (ALT: $118.40 \pm 5.52$ and ALP $320.40 \pm 18.92 \mathrm{U} / \mathrm{I}$ ), respectively compared to doxorubicin group.

The protective effect ... (Susilawati et al.,) 
The increasing value of ALT and ALP indicated the toxicity of liver tissue induces by doxorubicin. This finding agrees with Seif (2016) which reported that ALT and ALP are the specific biochemical parameters to detect liver damage or injury. The increasing number of ALT two-times than normal indicates the damage of liver tissue (Seif, 2016). Alshabanah et al. (2010) also reported that doxorubicin leads to increasing serum indices of liver function such as ALT and ALP, leading to hepatocellular damage and decreased liver function. The administration of the extract at a dose of $400 \mathrm{mg} / \mathrm{kg} \mathrm{BW}$ could reduce ALT and ALP levels compared to $200 \mathrm{mg} / \mathrm{kg} \mathrm{BW}$ dose in the group of rats with hepatotoxicity. In other words, $P$. emblica fruit ethanol extract had the effect of reducing ALT and ALP levels in the rats experiencing hepatotoxicity. This finding agrees with a previous study where the decreasing ALP and ALP level leads to recovery of treated rats liver cells (Chaphalkar et al., 2017; Pramyothin et al., 2006).

\section{Histopathological results}

Histopathological examination in this study was conducted to investigate $P$. emblica extract effect in doxorubicin-induced hepatotoxicity rats. The photomicrographs of the liver tissue histology of all treatment groups are shown in Figure 1.
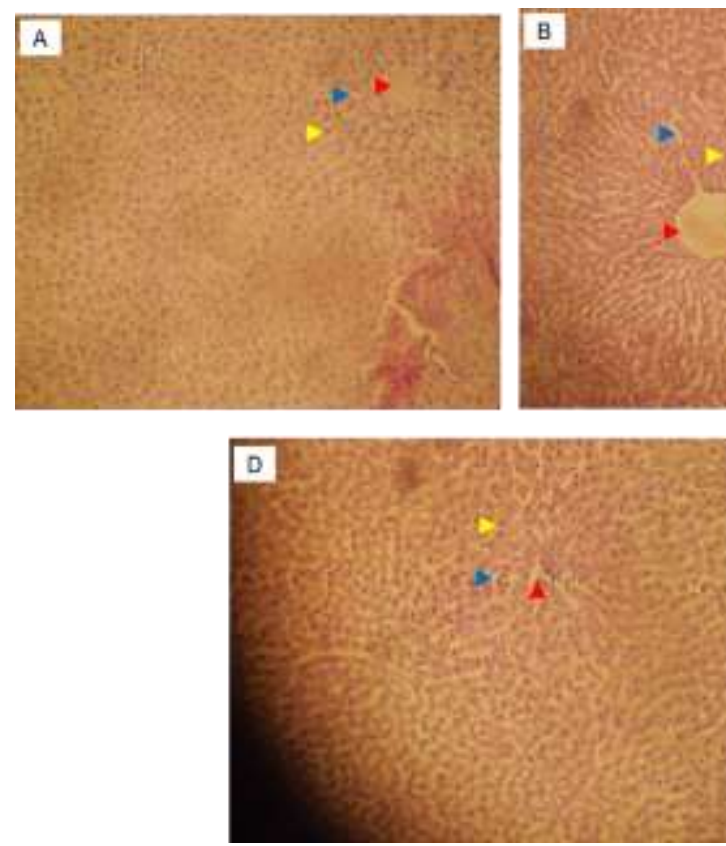

Central veins
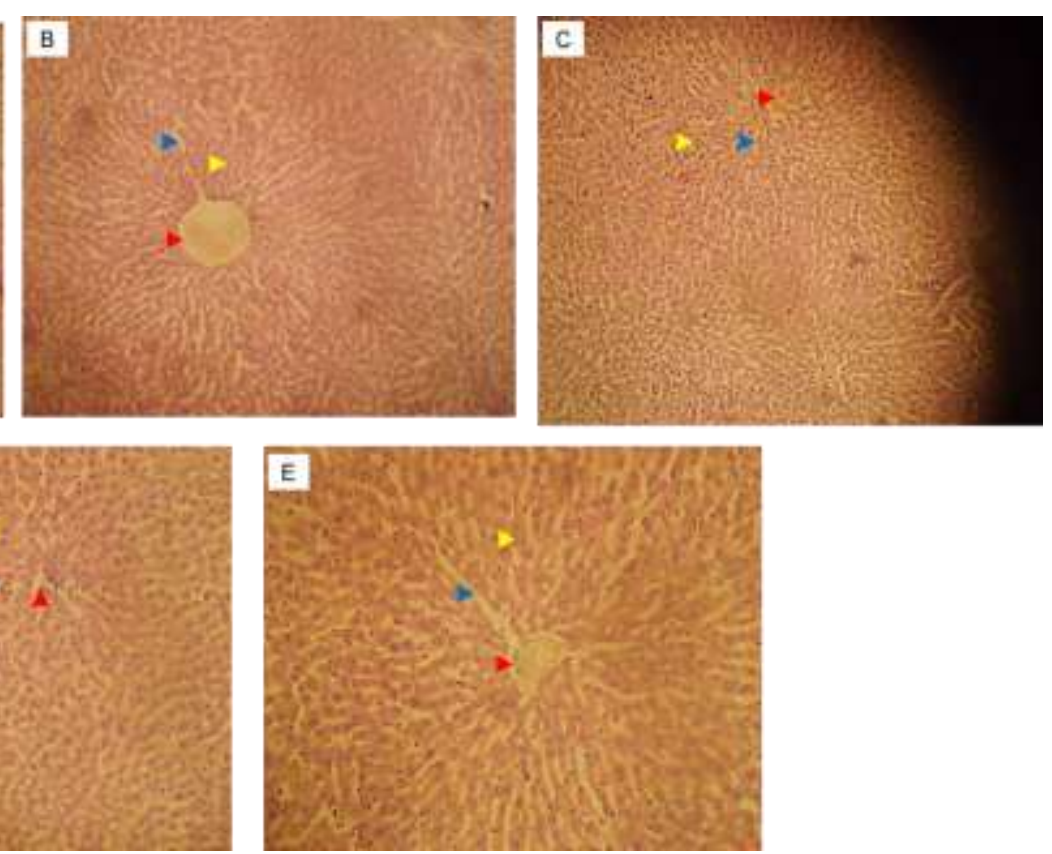

$\triangleright$ Hepatocytes

Sinusoid

Figure 1. Photomicrographs of liver histopathology in rats from normal treatment group A), doxorubicin $(25 \mathrm{mg} / \mathrm{kg} \mathrm{BW})$ only treatment group B), $P$. emblica extract C), $P$. emblica extract $200 \mathrm{mg} / \mathrm{kg} \mathrm{BW}+$ doxorubicin D), and $P$. emblica extract $400 \mathrm{mg} / \mathrm{kg}$ BW + doxorubicin $\mathrm{E}$ ) with 400x magnification

Figure 1 shows the photomicrographs from different group treatments. The normal group (Figure 1A) shows the normal hepatocytes, sinusoids, central veins, no interstitial bleeding, and no inflammatory cell infiltration. The doxorubicin group shows lysis and pyknotic cell nuclei at hepatocyte cells, blood vessel congestion, sinusoid interstitial bleeding, and inflammatory cell infiltration. In the doxorubicin group (Figure 1B), there was hepatocyte experiencing lysis and pyknotic cell nuclei (marked with a yellow triangle), blood vessel congestion (red triangle), and 
sinusoid interstitial bleeding (blue triangle). P. emblica extract at $200 \mathrm{mg} / \mathrm{kg} \mathrm{BW}$ shows the similarity of liver tissue to the normal group with little inflammatory cell's infiltration. In the treatment with an extract dose of $200 \mathrm{mg} / \mathrm{kg} \mathrm{BW}+$ doxorubicin (Figure 1D) and the treatment group with an extract dose of $400 \mathrm{mg} / \mathrm{kg} \mathrm{BW}+$ doxorubicin (Figure 1E), there was an improvement in the image of the rat liver tissue, which was indicated by the presence of normal hepatocytes more dominant than lysis (yellow triangle mark), slight signs of bleeding and congestion of blood vessels (red triangle mark) and sinusoids with lots of inflammatory cell infiltration (blue triangle mark). The treatments of $P$. emblica extract at $200 \mathrm{mg} / \mathrm{kg} \mathrm{BW}$ and $400 \mathrm{mg} / \mathrm{kg} \mathrm{BW}$ in doxorubicininduced rats show an improvement in liver tissue. The improvement of liver tissue was observed by the domination of normal hepatocytes than lysed cells, liver tissue repair, and increased inflammatory cell infiltration.

Doxorubicin damage of liver tissue leads to histopathological changes. Doxorubicin accelerates the free radicals production such as hydroxyl radicals, superoxide, and hydrogen peroxide that can quickly react to lipid caused lipid peroxidation (Rashid et al., 2013). Doxorubicin generates high lipid peroxidation of liver tissue in terms of hepatocytes generation and necrosis parenchyma (Rahmani et al., 2018). Lipid peroxidation produces free radicals such as alkoxyl, aldehyde, and peroxyl, which generate cellular damage and release of marker enzymes (Seif, 2016). The significant stage in the pathogenesis of doxorubicin toxicity is the inflammation caused by endogenous and migrating leucocytes (Rahmani et al., 2018). Several studies reported that lipid peroxidation of the heart and liver caused by reactive oxygen species leads to tissue damage induced by doxorubicin (Dodda et al., 2014; Kolarovic et al., 2009; Yagmurca et al., 2004). The polyunsaturated fatty acids in membrane lipids, protein, genetic materials, and hepatocytes were attacked by ROS which damages the liver (Rahmani et al., 2018). Antioxidants participate in scavenging free radicals and inhibiting cellular damage by delaying the lipid peroxidation process (Gulcin, 2020; Nimse and Pal, 2015). The improvements in the accumulation of leukocytes in liver tissue caused by antioxidant agents have been reported in the previous study (Tardif et al., 2014). Findings from this study which exhibit liver tissue improvement by $P$. emblica extract at various concentration, in doxorubicin-induced hepatotoxicity rats, agree with previous studies done that observed the antioxidant activity of $P$. emblica $L$. scavenging the free radicals and leading to improve liver tissue in tested rats (Hasan et al., 2016; Yaman et al., 2016; Charoenteeraboon et al., 2010; Tasduq et al., 2005).

\section{CONCLUSION}

The ethanol extract of Phyllanthus emblica L. contains alkaloids, flavonoids, phenolics, steroids/triterpenoids, terpenoids, and tannins. Both $200 \mathrm{mg} / \mathrm{kg} \mathrm{BW}$ and $400 \mathrm{mg} / \mathrm{kg} \mathrm{BW}$ of $P$. emblica extract show significantly decreased ALT and ALP levels and repair the liver tissue after doxorubicin-induced hepatotoxicity. These findings indicate the potential protective effect of $P$. emblica against doxorubicin toxicity in rat's hepar.

\section{ACKNOWLEDGEMENT}

The authors would like to acknowledge Universitas Prima Indonesia and Klinik Nadhira, Aek Kanopan in Labuhan Batu Utara for supporting and providing facilities. There is no funding supporting in this work.

\section{REFERENCES}

Akinpelu, B. , Igbeneghu, O. , Awotunde, A. , Iwalewa, E. , \& Oyedapo, O. (2014). Antioxidant and antibacterial activities of saponin fractions of Erythropheleum suaveolens (Guill. and Perri.) stem bark extract. Scientific Research and Essays, 18(9), 826-833. https://doi.org/10.5897/SRE2014.5844 
Alabri, T. H. A., Al Musalami, A. H. S., Hossain, M. A., Weli, A. M., \& Al-Riyami, Q. (2014). Comparative study of phytochemical screening, antioxidant and antimicrobial capacities of fresh and dry leaves crude plant extracts of Datura metel L. Journal of King Saud University, 26, 237-243. https://doi.org/http://dx.doi.org/10.1016/j.jksus.2013.07.002

Alshabanah, O. A., Hafez, M. M., Al-Harbi, M. M., Hassan, Z. K., Al Rejaie, S. S., Asiri, Y. A., \& Sayed-Ahmed, M. M. (2010). Doxorubicin toxicity can be ameliorated during antioxidant Lcarnitine supplementation. Oxidative Medicine and Cellular Longevity, 3(6), 428-433. https://doi.org/10.4161/oxim.3.6.14416

Chaphalkar, R., Apte, K. G., Talekar, Y., Ojha, S. K., \& Nandave, M. (2017). Antioxidants of Phyllanthus emblica L. Bark Extract Provide Hepatoprotection against Ethanol-Induced Hepatic Damage: A Comparison with Silymarin. Oxid Med Cell Longev, 2017, 3876040. https://doi.org/10.1155/2017/3876040

Charmkar, N. K., \& Singh, R. (2017). Emblica officinalis gaertn. (Amla): a wonder gift of nature to humans. International Journal of Current Microbiology and Applied Sciences, 6(7), 42674280. https://doi.org/10.20546/ijcmas.2017.607.442

Charoenteeraboon, J., Ngamkitidechakul, C., Soonthornchareonnon, N., Jaijoy, K., \& Sireeratawong, S. (2010). Antioxidant activities of the standardized water extract from fruit of Phyllanthus emblica Linn. Songklanakarin Journal of Science and Technology, 32(6), 599.

Damodar, G., Smitha, T., Gopinath, S., Vijayakumar, S., \& Rao, Y. (2014). An evaluation of hepatotoxicity in breast cancer patients receiving injection Doxorubicin. Annals of Medical and Health Sciences Research., 4(1), 74-79. https://doi.org/10.4103/2141-9248.126619

Dodda, D., Chhajed, R., \& Mishra, J. (2014). Protective effect of quercetin against acetic acid induced inflammatory bowel disease (IBD) like symptoms in rats: Possible morphological and biochemical alterations. Pharmacological Reports, 66(1), 169-173. https://doi.org/10.1016/j.pharep.2013.08.013

Edeoga, H. O., Okwu, D. E., \& Mbaebie, B. O. (2005). Phytochemical constituents of some Nigerian medicinalplants . African Journal of Biotechnology, 4(7), 685-688. https://doi.org/10.5897/AJB2005.000-3127

Godghate, A., \& Sawant, R. (2013). Qualitative phytochemical analysis of chloroform extract of leaves of Adhatoda Vasica Nees. Rasayan Journal of Chemistry, 6(2), 107-110.

Gulcin, İ. (2020). Antioxidants and antioxidant methods: an updated overview. Archives of Toxicology, 94(3), 651-715. https://doi.org/10.1007/s00204-020-02689-3

Hasan, M. R., Islam, M. N., \& Islam, M. R. (2016). Phytochemistry, pharmacological activities and traditional uses of Emblica officinalis: A review. International Current Pharmaceutical Journal, 5(2), 14-21.https:/doi.org/10.3329/icpj.v5i2.26441

Injac, R., \& Strukelj, B. (2008). Recent advances in protection against doxorubicin-induced toxicity. Technology in Cancer Research \& Treatment, 7(6), 497-516. https://doi.org/10.1177/153303460800700611

Kanthe, P., Patil, B. S., Aithala, M. R., \& Das, K. K. (2017). Effect of ethanolic extract of Emblica officinalis (amla) on glucose homeostasis in rats fed with high fat diet. Journal of Krishna Institute of Medical Sciences University, 6(3), 31-37.

Kementerian Kesehatan Republik, Indonesia. (2013). Peta Kesehatan Indonesia Tahun 2012.

King, P. D., \& Perry, M. C. (2001). Hepatotoxicity of chemotherapy. The Oncologist, 6(2), 162176. https://doi.org/10.1634/theoncologist.6-2-162

Kolarovic, J., Popovic, M., Mikov, M., Mitic, R., \& Gvozdenovic, L. (2009). Protective effects of celery juice in treatments with Doxorubicin. Molecules (Basel, Switzerland), 14(4), 16271638. https://doi.org/10.3390/molecules14041627

Luo, W., Zhao, M., Yang, B., Ren, J., Shen, G., \& Rao, G. (2011). Antioxidant and antiproliferative capacities of phenolics purified from Phyllanthus emblica L. fruit. Food 
Chem., 126(1), 277-282. https://doi.org/https://doi.org/10.1016/j.foodchem.2010.11.018

Mayachiew, P., \& Devahastin, S. (2008). Antimicrobial and antioxidant activities of Indian gooseberry and galangal extracts. LWT, 4l(7), 1153-1159. https://doi.org/https://doi.org/10.1016/j.lwt.2007.07.019

Mir, A. I., Kumar, B., Tasduq, S. A., Gupta, D. K., Bhardwaj, S., \& Johri, R. K. (2007). Phytochemistry, pharmacological activities and traditional uses of officinalis: A review. Indian Journal Experimental. Biology., 45, 626-629

Nimse, S. B., \& Pal, D. (2015). Free radicals, natural antioxidants, and their reaction mechanisms. RSC Advances, 5(35), 27986-28006. https://doi.org/10.1039/c4ra13315c

Nur, S., Rumiyati, R., \& Lukitaningsih, E. (2017). Screening of antioxidants, anti-aging and tyrosinase inhibitory activities of ethanolic and ethyl acetate extracts of fruit flesh and fruit peel langsat (Lansium domesticum Corr) in vitro. Majalah Obat Tradisional, 22(1), 63. https://doi.org/10.22146/tradmedj.24342

Nurhasnawati, H., Sundu, R., Sapri, S., Supriningrum, R., Kuspradini, H., \& Arung, E. T. (2019). Antioxidant activity, total phenolic and flavonoid content of several indigenous species of ferns in East Kalimantan, Indonesia. Biodiversitas, 20(2), 576-580. https://doi.org/10.13057/biodiv/d200238

Pedrycz, A., Wieczorski, M., \& Czerny, K. (2004). Increased apoptosis in the adult rat liver after a single dose of adriamycin administration. Annales Universitatis Mariae Curie-Skłodowska. Sectio D: Medicina, 59(2), 313-318

Pramyothin, P., Samosorn, P., Poungshompoo, S., \& Chaichantipyuth, C. (2006). The protective effects of Phyllanthus emblica Linn. extract on ethanol induced rat hepatic injury. Journal Ethnopharmacol., 107(3), 361-364. https://doi.org/10.1016/j.jep.2006.03.035

Rahmani, F., Najafizadeh, P., Mousavi, Z., Rastegar, T., \& Barzegar, E. (2018). The protective effect of quercetin against hepatotoxicity induced by doxorubicin in male rats. Irianian $J$. Pharmaclol, 16, 1-8.http://ijpt.iums.ac.ir/article-1-357-en.html

Rashid, S., Ali, N., Nafees, S., Ahmad, S. T., Arjumand, W., Hasan, S. K., \& Sultana, S. (2013). Alleviation of doxorubicin-induced nephrotoxicity and hepatotoxicity by chrysin in Wistar rats. Toxicol Mech Methods., 23(5), 337-345. https://doi.org/10.3109/15376516.2012.759306

Salouege, I., Ali, R. B., Saïd, D. B., Elkadri, N., Kourda, N., Lakhal, M., \& Klouz, A. (2014). Means of evaluation and protection from doxorubicin-induced cardiotoxicity and hepatotoxicity in rats. Journal of Cancer Research and Therapeutics., 10(2), 274-278.

Seif, H. S. A. (2016). Physiological changes due to hepatotoxicity and the protective role of some medicinal plants. Beni-Suef University Journal of Basic and Applied Sciences, 5(2), 134-146. https://doi.org/10.1016/j.bjbas.2016.03.004

Sharma R, Chaphalkar S, \& Adsool A. (2010). Evaluating antioxidant potential, cytotoxicity and intestinal absorption of flavonoids extracted from medicinal plants. International Journal of Biotechnology Applications, 2(1), 1-5. https://doi.org/10.9735/0975-2943.2.1.1-5

Sliai, A. M. (2015). Protective effects of wheat germ oil on doxorubicin-induced hepatotoxicity in male mice. International Journal of Research Studies in Biosciences (IJRSB), 3(6), 21-25.

Srivastava, P., Singh, M., Devi, G., \& Chaturvedi, R. (2014). Herbal medicine and biotechnology for the benefit of human health. In Animal Biotechnology (pp. 563-575). Elsevier. https://doi.org/10.1016/B978-0-12-416002-6.00030-4

Sriwatcharakul, S. (2020). Evaluation of bioactivities of Phyllanthus emblica seed. Energy Reports, 6, 442-447. https://doi.org/10.1016/j.egyr.2019.08.088

Sultana, S., Ahmad, S., Khan, N., \& Jahangir, T. (2005). Effect of Emblica officinalis (Gaertn) on $\mathrm{CCl} 4$ induced hepatic toxicity and DNA synthesis in Wistar rats. Indian Journal of Experimental Biology, 43(5), 430-436.

Tardif, S., Madamidola, O. A., Brown, S. G., Frame, L., Lefièvre, L., Wyatt, P. G., Barratt, C. L., \& Martins Da Silva, S. J. (2014). Clinically relevant enhancement of human sperm motility 
using compounds with reported phosphodiesterase inhibitor activity. Hum Reprod., 29(10), 2123-2135. https://doi.org/10.1093/humrep/deu196

Tasduq, S. A., Kaisar, P., Gupta, D. K., Kapahi, B. K., Jyotsna, S., Maheshwari, H. S., \& Johri, R. K. (2005). Protective effect of a 50\% hydroalcoholic fruit extract of Emblica officinalis against anti-tuberculosis drugs induced liver toxicity. Phytotherapy Research, 19(3), 193197. https://doi.org/10.1002/ptr.1631

Wang, C. C., Yuan, J. R., Wang, C. F., Yang, N., Chen, J., Liu, D., Song, J., Feng, L., Tan, X. Bin, \& Jia, X. Bin. (2017). Anti-inflammatory Effects of Phyllanthus emblica L on BenzopyreneInduced Precancerous Lung Lesion by Regulating the IL-1 $/$ miR-101/Lin28B Signaling Pathway. Integrative Cancer Therapies, 16(4), 505-515. https://doi.org/10.1177/1534735416659358

WHO. (2010). Global status report on noncommunicable diseases 2010.

Yagmurca, M., Erdogan, H., Iraz, M., Songur, A., Ucar, M., \& Fadillioglu, E. (2004). Caffeic acid phenethyl ester as a protective agent against doxorubicin nephrotoxicity in rats. Clinica Chimica Acta, 348(1-2), 27-34. https://doi.org/10.1016/j.cccn.2004.03.035

Yaman, T., Yener, Z., \& Celik, I. (2016). Histopathological and biochemical investigations of protective role of honey in rats with experimental aflatoxicosis. BMC Complementary and Alternative Medicine, 16(1), 232. https://doi.org/10.1186/s12906-016-1217-7

Zimmermann-Ivol, C. G., Burkhard, P. R., Le Floch-Rohr, J., Allard, L., Hochstrasser, D. F., \& Sanchez, J.-C. (2004). Fatty acid binding protein as a serum marker for the early diagnosis of stroke: A pilot study. Molecular and Cellular Proteomics, 3(1), 66-72. https://doi.org/10.1074/mcp.M300066-MCP200 